\title{
Diel variations in frequency of dividing cells and abundance of aerobic anoxygenic phototrophic bacteria in a coral reef system of the South China Sea
}

\author{
Rulong Liu, Yao Zhang, Nianzhi Jiao* \\ State Key Laboratory of Marine Environmental Science, Xiamen University, Xiamen 361005, China
}

\begin{abstract}
With the ability of photoheterotrophic metabolism, aerobic anoxygenic phototrophic (AAP) bacteria are an important bacterial group in the marine microbial community. We investigated the diel variations of AAP bacteria in the coral reef water of the South China Sea, and report, for the first time, the frequency of dividing cells (FDC) of AAP bacteria. Our results showed that AAP bacterial abundance ranged from $1.54 \times 10^{4} \pm 3.21 \times 10^{2}$ to $3.59 \times 10^{4} \pm 3.04 \times 10^{3} \mathrm{cells} \mathrm{ml}^{-1}$. The diel pattern of AAP bacterial abundance had 2 peak values, one at night around 21:00 $\mathrm{h}$ and the other in the daytime at around 9:00 h. Tidal current and light were the primary factors controlling the diel variations of AAP bacteria in this area during our study period. FDC values in AAP and total bacteria were both higher during the night than during the day. The FDC values in AAP bacteria (3.53 \pm 1.09 to 9.43 $\pm 0.80 \%$ ) were significantly higher than those in total bacteria (1.06 \pm 0.06 to $3.14 \pm 1.38 \%$ ), indicating higher growth rate of AAP bacteria than total bacteria in the study area.
\end{abstract}

KEY WORDS: Aerobic anoxygenic phototrophic (AAP) bacteria - Diel variation - Frequency of dividing cells $\cdot$ FDC $\cdot$ Abundance

Resale or republication not permitted without written consent of the publisher

\section{INTRODUCTION}

Aerobic anoxygenic phototrophic (AAP) bacteria are a functional group of microorganisms that can utilize light energy and play a particular role in carbon cycling in the ocean (Kolber et al. 2000, 2001). These bacteria form 0.5 to $16 \%$ of the total bacteria in the euphotic zone of various marine environments (Kolber et al. 2001, Cottrell et al. 2006, Jiao et al. 2007, Zhang \& Jiao 2007). They depend on aerobic respiration based on organic substrates for growth, but also derive a significant portion of their energy requirements from light through bacteriochlorophyll a (Bchl a)-containing reaction centers (Rathgeber et al. 2004).

Previous research on diel changes of AAP bacteria in marine environments focused on Bchl a concentration (Koblizek et al. 2005, 2007) or photochemistry signals (Kolber et al. 2000). Clear and large diurnal changes in
Bchl a contents were reported in the Baltic Sea (Koblizek et al. 2005) and the euphotic zone of the Atlantic Ocean (Koblizek et al. 2007). A distinct decline of pigment occurring during daylight hours was ascribed to the complete inhibition of Bchl a synthesis by light, in combination with a concurrent turnover of the cells (Koblizek et al. 2005). However, research carried out in the surface water of the Pacific indicated the absence of a diel cycle in bacterial photosynthesis, implying a lack of photoinhibition and no diel coherence in cell division (at least as indicated by photochemistry; Kolber et al. 2000). There are few data concerning the growth rate of AAP bacteria in the field. Koblizek et al. (2007) reported the AAP bacterial growth rate in the Atlantic Ocean, assessed from the diel cycle rate of Bchl a concentration. In the present study, we investigated diel variations of abundance and frequency of dividing cells (FDC) of AAP bacteria 
in a coral reef system near Yongxing Island $\left(112.32^{\circ} \mathrm{E}\right.$, $16.83^{\circ} \mathrm{N}$ ) in the South China Sea. Time series observation was conducted from 21 to 25 February 2006 in the coral reef system near Yongxing Island. Combining the Time-series observation based InfraRed Epifluorescence Microscopy protocol (Jiao et al. 2006) and the FDC method for bacterial growth rate estimation (Hagstrom et al. 1979), provided us with an alternative way to assess AAP bacterial growth rate. This work was aimed at examining the differences between AAP and total bacteria in diel variation as well as their controlling mechanisms.

\section{MATERIALS AND METHODS}

Water sampling. The reef rim surrounding Yongxing Island supports a coral community dominated by Acropora spp. (Li et al. 2004). Our study site, located about $250 \mathrm{~m}$ from the coast, was a shallow water environment with a depth of 3 to $5 \mathrm{~m}$. Diurnal samples were collected from the surface water at $3 \mathrm{~h}$ intervals. Briefly, subsamples for AAP and total bacterial abundance analysis were collected using $100 \mathrm{ml}$ brown polypropylene bottles. Immediately after sampling, triplicate $20 \mathrm{ml}$ seawater samples were fixed with paraformaldehyde (1\% final concentration, $20 \mathrm{~min})$ and stained with 4'6-diamidino-2-phenylindole (DAPI; $5 \mathrm{mg} \mathrm{ml}^{-1}$ final concentration) and then filtered onto $25 \mathrm{~mm}$ diameter, $0.2 \mu \mathrm{m}$ pore-size black polycarbonate (PC) membranes (Whatman) for microscopic observation. They were stored at $-20^{\circ} \mathrm{C}$ before analysis. Triplicate $2 \mathrm{ml}$ subsamples were fixed with glutaraldehyde ( $0.5 \%$ final concentration, $20 \mathrm{~min}$ ) and stored at $-80^{\circ} \mathrm{C}$ for analysis of autotrophic picoplankton abundance by flow cytometry. For chl a concentration, triplicate $200 \mathrm{ml}$ water samples were filtered directly onto $47 \mathrm{~mm}$ diameter GF/F membranes (Whatman) and stored at $-20^{\circ} \mathrm{C}$ before analysis. Surface water temperature was monitored continuously using a Yellow Springs Instrument (YSI) meter (YSI6600), and the precision of the YSI probes was $0.01^{\circ} \mathrm{C}$ for temperature. Light intensity (solar radiation intensity) was measured using a radiometer (Delta OHM HD2302). The data of tidal height came from the observation station on Xisha Island.

Determination of abundance of AAP and total bacteria. Abundance of AAP bacteria was determined using an advanced 'Time-series observation based cyanobacteria calibrated InfraRed Epifluorescence Microscopy (TIREM)' protocol, which was described by Jiao et al. (2006). Infrared fluorescence from Bchl a was the diagnostic signal of AAP bacteria. Cells were viewed with an infrared-sensitive charge-coupled device (CCD) camera (DP30 Diagnostic Instruments) on an epifluorescence microscope with a $100 \mathrm{~W}$ mercury lamp (Olympus Light Microscopy BX61). DAPIstained images (DAPI-images), cyanobacterial images (Cyano-images), and infrared images (IR-images) were acquired for each microscopic view field using a $100 \times$ oil immersion objective. All images were captured using automatic exposure with a gain limit of 8 . Time series images of DAPI-, Cyano-, and IR-images were obtained for 10 to $15 \mathrm{~min}$ at intervals of $60 \mathrm{~s}$ from the start of the exposure. Image analysis was conducted to obtain dynamic curves of IR-, Cyano-, and DAPI-counts from each microscopic view field. The accurate estimation of AAP bacteria was calculated from the formula: AAP counts = (plateau count of infrared positive cells)-(plateau count of cyanobacterial cells) (Jiao et al. 2006). Thirty microscopic fields of each sample were viewed, and the means were multiplied by appropriate factors $\left(A_{1} / A_{2} / V\right.$, where $A_{1}$ is the area of a filter, $A_{2}$ is the area of 1 microscopic view field, and $V$ is the volume of water filtered) to yield AAP bacterial concentrations in the original samples. Abundance of total bacteria was obtained by directly counting DAPI-images acquired in the TIREM procedure and multiplication by the same factors as AAP bacteria.

Determination of FDC. FDC in total bacterial cells was counted according to Hagstrom et al. (1979) and Fukuda et al. (2006). A cell was counted as dividing if a clear invagination of the cell wall could be seen, but not a clear separatory space between daughter cells. DAPI images captured in the TIREM procedure were used for observation of dividing cells for total bacteria. Fifteen microscopic fields (average 130 cells field ${ }^{-1}$ ) and a minimum of 30 dividing bacterial cells were counted for each sample. For determination of the FDC of AAP bacteria, a combination of the TIREM approach (Jiao et al. 2006) and the method for identifying dividing cells (Hagstrom et al. 1979) was used. Firstly, we picked out the AAP bacteria cells by comparing Cyano-images, IR-images, and DAPI-images captured in the TIREM procedure and subtracting the Cyanopositive cells from the IR-images. To do this, images needed to be processed in Image-Pro Plus (IPP) software (Media Cybernetic, version 6.0). The IR-images were stained with red color using the tint function in IPP, and Cyano-images were stained with green color. IR- and Cyano- images from the same microscopic field were merged together to form a new image using the merge function in IPP. The cells that retained red color in the merged image and could be found in the same position in the corresponding DAPI-image were AAP bacteria. The local zoom function in IPP was applied to enlarge these cells in order to clearly show their features. We then identified the dividing cells in the AAP cells using the same standard as that for total 
bacteria described at the beginning of this section. Thirty microscopic fields of each sample were counted. The FDC of both AAP and total bacterial cells were calculated using the following formula: FDC $(\%)=$ abundance of dividing cells $\times 100 /$ abundance of AAP (or total bacteria).

Determination of $\mathrm{chl} a$, nutrient concentration, and autotrophic picoplankton abundance. Chl a concentration was determined fluorometrically (Parsons et al. 1984) with a Turner Designs Model 10 fluorometer (Sigma). Dissolved inorganic phosphate (DIP; $\mathrm{PO}_{4}{ }^{3-}$ ) and inorganic nitrogen (DIN; $\mathrm{NO}_{3}{ }^{-}, \mathrm{NO}_{2}{ }^{-}$) were measured using the standard molybdenum blue procedure and the standard pink azo dye method (Pai et al. 1990a,b), respectively. The precision of the methods was about $4 \%$ for DIP and $1 \%$ for DIN. Generally, surface nutrients in the oligotrophic ocean are found at the nano-mole level and, in our study area, surface DIN $(<0.3 \mu \mathrm{M})$ was below the detection limit. Abundances of picoeukaryotes, Synechococcus, and Prochlorococcus were determined by flow cytometry (Jiao et al. 2002) on an Epics Altra II (Beckman Coulter) flow cytometer, equipped with a 306C-5 argon laser (Coherent).

\section{RESULTS}

\section{Environmental parameters}

The tide was irregularly diurnal, with the highest water level at about 18:00 $\mathrm{h}$ and the lowest at around 0:00-03:00 h (Fig. 1). The light intensity was strongest from 12:00 to 15:00 $\mathrm{h}$ in this area (Fig. 1). During our observation period, the diel changes of water temperature ranged from 23.30 to $27.68^{\circ} \mathrm{C}$, with the highest value at around 15:00 $\mathrm{h}$ and the lowest at around 06:00 $\mathrm{h}$ (Fig. 1). Diel changes in the concentration of DIP in the water were not as clear as those in tide and temperature. In the diurnal observation during 21 to 23 February, the changes in DIP concentration were not pronounced, and the values fluctuated around 74.08 nM. However, during 23 to 25 February, a rapid increase in DIP concentration occurred at night (around 18:00 to 21:00 h), reaching values twice as high as the lowest value in the daytime (Fig. 1).

\section{Diel changes in AAP and total bacterial abundance}

Abundance of AAP bacteria showed obvious diel changes, with values ranging from $( \pm \mathrm{SD}) 1.54 \times 10^{4} \pm$ $3.21 \times 10^{2}$ to $3.59 \times 10^{4} \pm 3.04 \times 10^{3}$ cells ml ${ }^{-1}$. The highest value occurred at around 21:00 $\mathrm{h}$ and dropped to the lowest value at around 00:00 h of the next day, and then the value rose until 09:00 h. After that, the value dropped again at around 12:00 $\mathrm{h}$ and then rose until 21:00 h (Fig. 2a). The diel change in AAP bacterial abundance during 23 to 25 February was more obvious than that during 21 to 23 February, especially for the changes during the day (Fig. 2a).

The values of total bacterial abundance $( \pm \mathrm{SD})$ ranged from $5.32 \times 10^{5} \pm 1.07 \times 10^{5}$ to $1.80 \times 10^{6} \pm 1.88$ $\times 10^{5}$ cells $\mathrm{ml}^{-1}$. The diel pattern of total bacterial abundance was similar to that of AAP bacteria, but the changes during the day were $3 \mathrm{~h}$ behind those of AAP bacteria (Fig. 2b). The highest value of total bacterial abundance in the night occurred at around 21:00 $\mathrm{h}$ and lowest value at 00:00 to 03:00 h, while in the day, the highest values occurred at 12:00 $\mathrm{h}$ and the lowest values occurred during $15: 00$ to $18: 00 \mathrm{~h}$ (Fig. 2b). 


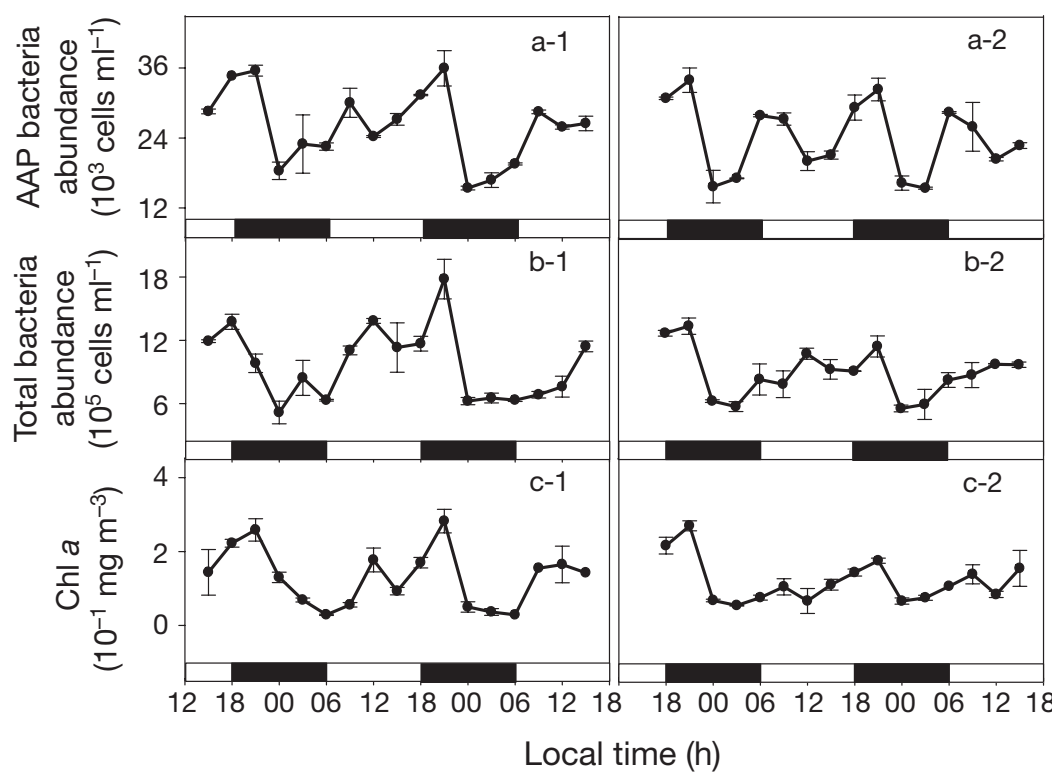

Fig. 2. Diel variations in (a) aerobic anoxygenic phototrophic (AAP) bacterial abundance, (b) total bacterial abundance, and (c) chl a concentration in the surface water of the sampling site. Diurnal observations were made from 21 to 23 (left, 1) and 23 to 25 (right, 2) February 2006. Horizontal black (white) bars show night (day). Error bars indicate the SD of triplicate measurements

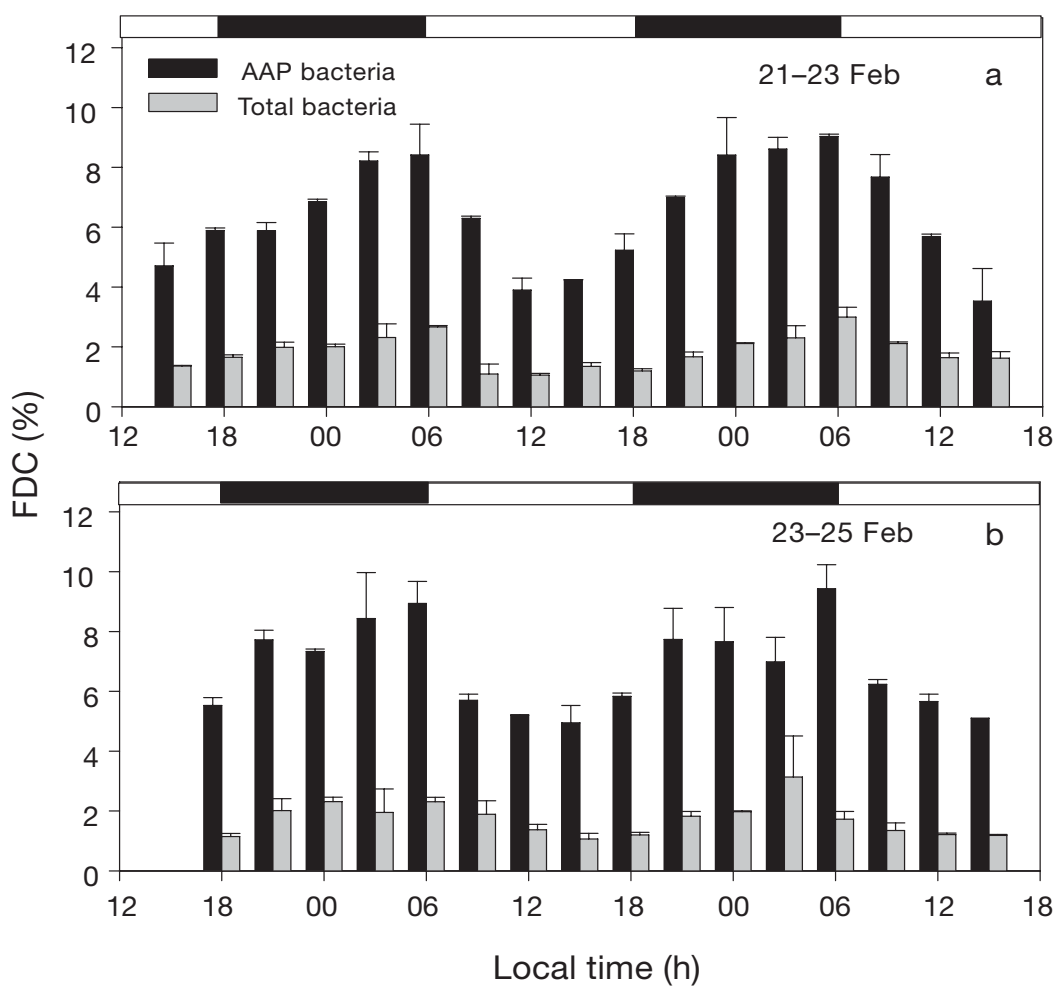

Fig. 3. Diel changes in the frequency of dividing cells (FDC) of aerobic anoxygenic phototrophic (AAP) bacteria (black columns) and total bacteria (grey columns) during (a) 21 to 23 and (b) 23 to 25 February 2006. Horizontal black (white) bars show night (day). Error bars indicate the SD of triplicate measurements
Diel changes in chl a concentration and autotrophic picoplankton abundance

In the diurnal observation of 21 to 23 February, the concentration of chl a showed an obvious diel change, basically similar to that of total bacterial abundance (Fig. 2c). The highest concentrations of chl a were measured at 18:00 to $21: 00 \mathrm{~h}$, and the lowest values were at midnight or just before dawn. Also, during the day there was an increase from 06:00 to $12: 00 \mathrm{~h}$ and a decrease after 12:00 $\mathrm{h}$. In contrast, in the diurnal observation of 23 to 25 February, chl a concentrations were lower than the first observation, especially during the whole day from 24 to 25 February (Fig. 2c). The autotrophic picoplankton abundance (Appendix 1, Fig. A1) showed a similar diel pattern to that of chl a contents in the diurnal observation of 21 to 23 February, while in the observation of 23 to 25 February, the diel changes were less pronounced (Fig. A1).

\section{Diel changes in the FDC of AAP and total bacteria}

Diel patterns of FDC were similar for both AAP and total bacteria: higher values during the night and lower values during the day. The peak values in the diurnal cycles were at 03:00 to 06:00 $\mathrm{h}$ and then decreased until 12:00 to 15:00 h (Fig. 3). Thereafter, the FDC values began to increase until the next peak value at night. The range in FDC of AAP bacteria $( \pm \mathrm{SD})$ during our observation period was from $3.53 \pm 1.09$ to $9.43 \pm 0.80 \%$, while the FDC of total bacteria $( \pm \mathrm{SD})$ ranged from $1.06 \pm$ 0.06 to $3.14 \pm 1.38 \%$. The FDC of AAP bacteria was about 2.17 to 5.75 times that of the total bacteria (Fig. 3).

\section{DISCUSSION}

\section{Diel variation in AAP abundance and possible regulation parameters}

During our study period, a distinct diel pattern of AAP bacterial abundance was observed in this coral reef system, that is, abundance of AAP bacteria showed 2 peaks during a day-night cycle (Fig. 2a). 

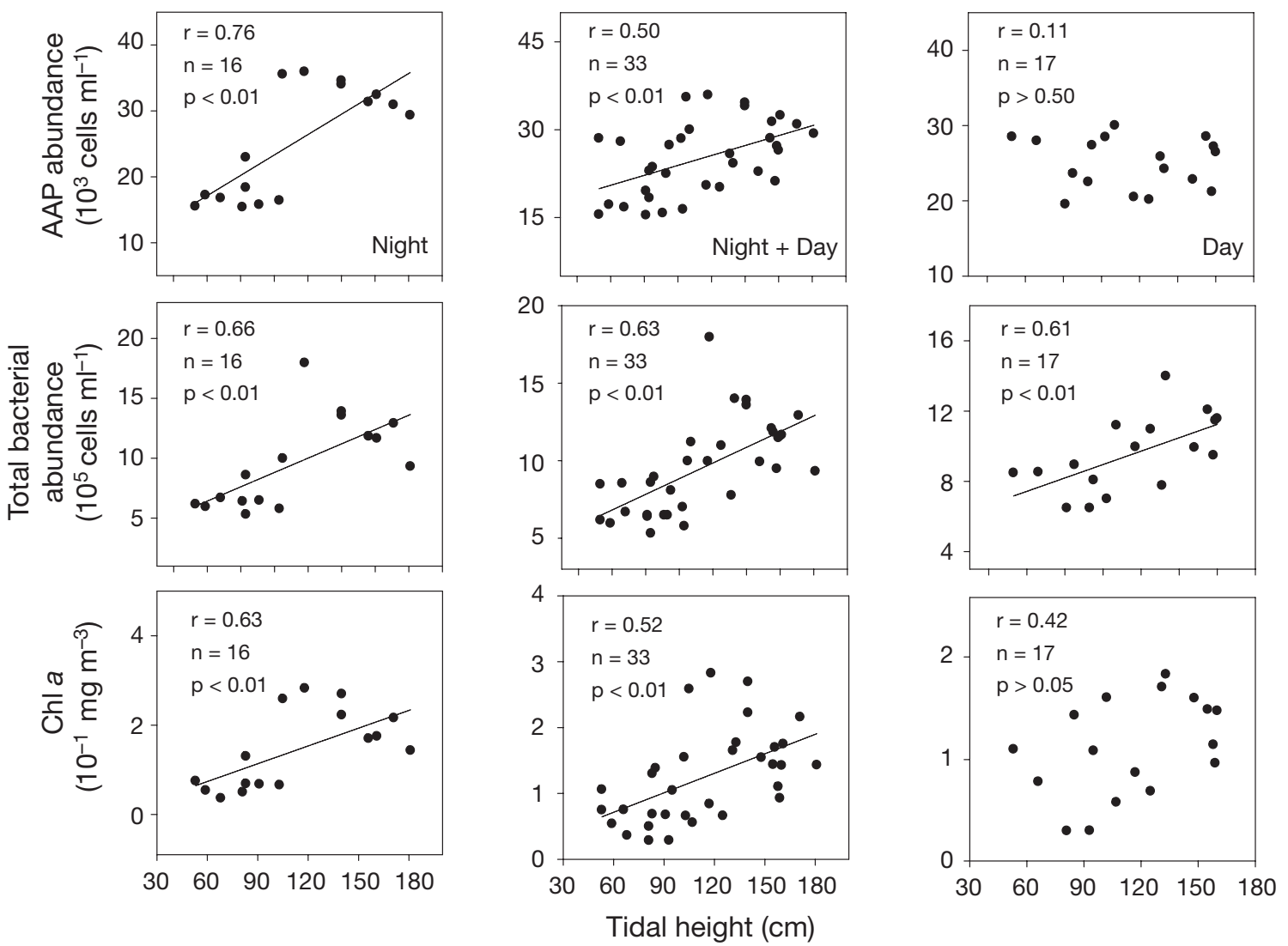

Fig. 4. Correlations between changes in aerobic anoxygenic phototrophic (AAP) bacterial abundance, total bacterial abundance, or chl a concentration and tidal height during night time (left), daytime (right), and the whole day (middle)

This pattern might be due to this particular ecosystem, which is shallow, with high productivity and activity of coral, and is affected by tidal cycle, light intensity, temperature, nutrients, and other factors.

Of the environmental factors we measured, variations in tidal height were most similar to those of AAP bacterial abundance, especially at night (Figs. $1 \& 2$ ). The highest and lowest values of AAP bacterial abundance at night happened at the times nearest to the highest and lowest water levels, indicating close relationships between AAP bacterial abundance and tidal currents (Fig. 4). Meanwhile, the changes of total bacterial abundance and chl a concentration at night were also close to those of tidal height (Fig. 4). In such a shallow coral reef ecosystem, the potential interactions between tidal current and organisms are described as follows: (1) During the flood tide, a large number of heterogenous organisms from the surrounding water (Sorokin 1994), coral surface mucus (Huettel et al. 2006), and sediments enter into the water covering the coral reef. Meanwhile, growth of local organisms during the flood tide could also be a reason for increasing biomass. (2) Increased biomass of small organisms stimulates the activity of consumers, which in turn lim- its further increase of pico-sized organisms. (3) During the ebb tide, many organisms are carried to the surrounding water (Sorokin 1994), stick to the coral mucus (Huettel et al. 2006), or settle to the bottom. Our results could provide some evidence of such processes. Here, the abundance of Prochlorococcus (Appendix 1, Fig. A1), which is much more abundant in the oligotrophic environment (Partensky et al. 1999) and is normally negatively related to other picoplankton in biomass distribution (Zhang et al. 2008), increased greatly along with the other autotrophic picoplankton with the flood tide during 21 to 23 February, indicating an intrusion of non-local organisms from the peripheral oligotrophic water sources.

During the day, the close correlation between AAP bacterial abundance and tidal height was broken (Fig. 4), suggesting that changes in AAP bacterial abundance might be controlled by factors other than just tidal current. High abundance from 06:00 to 09:00 h might result from cell division at 03:00 to $06: 00 \mathrm{~h}$, when FDC values were the highest during the diurnal changes (Fig. 3). Cell division leading to the high abundance in the morning has also been revealed in previous research (Kuipers et al. 2000). The decrease 
of AAP abundance during 12:00 to $15: 00 \mathrm{~h}$ might be a result of a combination of slow growth (Fig. 3) and light inhibition. Our research area was a shallow coral reef system, and solar radiation was most intense at around 12:00 to $15: 00 \mathrm{~h}$ (Fig. 1), when the growth of bacteria could be inhibited and photo-induced cell lysis could occur (Müller-Niklas et al. 1995, Pakulski et al. 1998). In addition, viral lysis of bacteria mainly occurs around noon to afternoon (Winter et al. 2004), which might be another factor leading to a drop in AAP abundance at noon.

\section{Diel variations of FDC of AAP bacteria versus total bacteria}

In the present study, we observed for the first time the dividing cells of AAP bacteria using epifluorescence microscopy, which is a convenient and direct method for assessing bacterial growth rates (Hagstrom et al. 1979, Newell \& Christian 1981, Fukuda et al. 2006). Observations of dividing cells have been conducted for many organisms, such as heterotrophic microprotozoa (Sherr \& Sherr 1983), autotrophic picoplankton (Affronti \& Marshall 1994), and heterotrophic bacteria (Hagstrom et al. 1979, Newell \& Christian 1981, Fukuda et al. 2006), but no application to AAP bacteria has been reported to date.

The FDC of AAP and total bacteria showed clear diel patterns, with higher values during the night and lower values during the day (Fig. 3). Similar diel patterns have been reported for FDC of heterotrophic bacteria by Kuipers et al. (2000). Also, FDC values of picophytoplankton were higher in the early evening in natural environments (Campbell \& Carpenter 1986). These similarities indicated that the pattern of higher division rate during night might be prevalent in marine microorganisms. Cell division accomplished mainly in darkness may avoid exposure of DNA to potentially harmful UV radiation during cell division (Kuipers et al. 2000).

\section{Growth rates of AAP versus total bacteria implied by FDC}

Our results revealed significantly higher FDC of AAP bacteria than of total bacteria (paired $t$-test, $\mathrm{p}<$ 0.001; Fig. 3). According to the positive relationships between FDC and growth rates as reviewed by Newell et al. (1986), higher FDC of AAP bacteria indicates higher growth rates. Based on the FDC data, we estimated the growth rate $(\mu)$ of AAP and total bacteria using the formula proposed by Newell \& Christian (1981): ln $\mu=0.299 F D C-4.961$. The results showed that the growth rate $( \pm \mathrm{SD})$ of AAP bacteria in this area was $0.50 \pm 0.16$ to $2.86 \pm 0.68 \mathrm{~d}^{-1}$ (Appendix 1, Fig. A2), and the average generation time $(\ln 2 / \mu)$ was about $15 \mathrm{~h}$. The growth rate $( \pm \mathrm{SD})$ of total bacteria was 0.23 \pm 0.00 to $0.45 \pm 0.18 \mathrm{~d}^{-1}$ (Appendix 1, Fig. A2), with an average generation time of about $60 \mathrm{~h}$. The average growth rate of AAP was about 4 times of that of total bacteria). Similar higher growth rates of AAP bacteria than total bacteria were also reported in the productive North Atlantic (Koblizek et al. 2007). Given that the cell sizes of AAP bacteria are usually larger than those of other bacteria (Lami et al. 2007, Zhang et al. 2008, AAP bacteria may play a more important role than suggested by their abundance in carbon cycling in the ocean.

Although the estimation of bacterial growth rate through the FDC approach is rough, it provides a way to distinguish AAP production from total bacteria, which is impossible for traditional methods such as ${ }^{3} \mathrm{H}-$ adenine incorporation (Christian et al. 1982). However, we must point out that conclusions from the FDC approach should be viewed with caution given potentially unbalanced growth of different types of bacteria in the calibration experiments (Newell et al. 1986), diverse positive relationships between growth rates and FDC (linear or non-linear; Newell \& Christian 1981, Newell et al. 1986), and other factors. Further studies are needed for accurate assessment of AAP bacterial growth rate.

Acknowledgements. We thank M.H. Dai for the sampling opportunities and H.Y. Zhang for assistance in collecting the samples during the cruises. We also thank Z.M. Lu, Z.M. Cao, and Y.P. $\mathrm{Xu}$ for performing the environmental parameter measurements. F. Zhang and T.W. Luo assisted in fluorometry and flow cytometry analysis, respectively. This work was supported by the NSFC Project 40632013, the 973 Project 2007CB815904, the SOA Project 200805068, and the NSFC Project 40821063. We thank J. Hodgkiss for assistance with the English.

\section{LITERATURE CITED}

Affronti LF, Marshall HG (1994) Using frequency of dividing cells in estimating autotrophic picoplankton growth and productivity in the Chesapeake Bay. Hydrobiologia 284: 193-203

> Campbell L, Carpenter EJ (1986) Diel patterns of cell division in marine Synechococcus spp. (Cyanobacteria): use of the frequency of dividing cells technique to measure growth rate. Mar Ecol Prog Ser 32:139-148

Christian RR, Hanson RB, Newell SY (1982) Comparison of methods for measurement of bacterial growth rates in mixed batch cultures. Appl Environ Microbiol 43: 1160-1165

> Cottrell MT, Mannino A, Kirchman DL (2006) Aerobic anoxygenic phototrophic bacteria in the Mid-Atlantic Bight and the North Pacific Gyre. Appl Environ Microbiol 72: $557-564$ 
Fukuda M, Matsuyama J, Katano T, Nakano S, Dazzo F (2006) Assessing primary and bacterial production rates in biofilms on pebbles in Ishite Stream, Japan. Microb Ecol $52: 1-9$

Hagstrom A, Larsson U, Horstedt P, Normark S (1979) Frequency of dividing cells, a new approach to the determination of bacterial growth rates in aquatic environments. Appl Environ Microbiol 37:805-812

Huettel M, Wild C, Gonelli S (2006) Mucus trap in coral reefs: formation and temporal evolution of particle aggregates caused by coral mucus. Mar Ecol Prog Ser 307:69-84

Jiao NZ, Yang YH, Koshikawa H, Watanabe M (2002) Influence of hydrographic conditions on picoplankton distribution in the East China Sea. Aquat Microb Ecol 30:37-48

Jiao N, Zhang Y, Chen Y (2006) Time series observation based InfraRed Epifluorescence Microscopic (TIREM) approach for accurate enumeration of bacteriochlorophyllcontaining microbes in marine environments. J Microbiol Methods 65:442-452

Jiao N, Zhang Y, Zeng Y, Hong N, Liu R, Chen F, Wang P (2007) Distinct distribution pattern of abundance and diversity of aerobic anoxygenic phototrophic bacteria in the global ocean. Environ Microbiol 9:3091-3099

Koblizek M, Ston-Egiert J, Sagan S, Kolber ZS (2005) Diel changes in bacteriochlorophyll a concentration suggest rapid bacterioplankton cycling in the Baltic Sea. FEMS Microbiol Ecol 51:353-361

Koblizek M, Masin M, Ras J, Poulton AJ, Prasil O (2007) Rapid growth rates of aerobic anoxygenic phototrophs in the ocean. Environ Microbiol 9:2401-2406

Kolber ZS, Van Dover CL, Niederman RA, Falkowski PG (2000) Bacterial photosynthesis in surface waters of the open ocean. Nature 407:177-179

Kolber ZS, Plumley FG, Lang AS, Beatty JT and others (2001) Contribution of aerobic photoheterotrophic bacteria to the carbon cycle in the ocean. Science 292:2492-2495

Kuipers B, van Noort GJ, Vosjan J, Herndl GJ (2000) Diel periodicity of bacterioplankton in the euphotic zone of the subtropical Atlantic Ocean. Mar Ecol Prog Ser 201:13-25

Lami R, Cottrell MT, Ras J, Ulloa O and others (2007) High abundances of aerobic anoxygenic photosynthetic bacteria in the South Pacific Ocean. Appl Environ Microbiol 73: 4198-4205

Li YH, Huang XP, Yue WZ, Lin YT, Zou R, Huang H (2004) Ecological study of coral reef and intertidal benthos around Yongxing island, South China Sea. Oceanol Limnol Sin 35:176-182
Müller-Niklas G, Heissenberger A, Puskarit S, Herndl GJ (1995) Ultraviolet-B radiation and bacterial metabolism in coastal waters. Aquat Microb Ecol 9:111-116

> Newell SY, Christian RR (1981) Frequency of dividing cells as an estimator of bacterial productivity. Appl Environ Microbiol 42:23-31

Newell SY, Fallon RD, Tabor PS (1986) Direct microscopy of natural assemblages. In: Pointdexter JS, Leadbetter ER (eds) Bacteria in nature, Vol 2. Plenum, New York, p 1-48

Pai SC, Yang CC, Riley JP (1990a) Formation kinetics of the pink azo dye in the determination of nitrite in natural waters. Anal Chim Acta 232:345-349

Pai SC, Yang CC, Riley JP (1990b) Effects of acidity and molybdate concentration on the kinetics of the formation of the phosphoantimonylmolybdenum blue complex. Anal Chim Acta 229:115-120

Pakulski JD, Aas P, Jeffrey W, Lyons M, van Waasbergen LG, Mitchell D, Coffin R (1998) Influence of light on bacterioplankton production and respiration in a subtropical coral reef. Aquat Microb Ecol 14:137-148

Parsons TR, Maita Y, Lalli CM (1984) A manual of chemical and biological methods for seawater analysis. Pergamon Press, New York, NY

Partensky F, Hess WR, Vaulot D (1999) Prochlorococcus, a marine photosynthetic prokaryote of global significance. Microbiol Mol Biol Rev 63:106-127

> Rathgeber C, Beatty JT, Yurkov V (2004) Aerobic phototrophic bacteria: new evidence for the diversity, ecological importance and applied potential of this previously overlooked group. Photosynth Res 81:113-128

Sherr EB, Sherr BF (1983) Double-staining epifluorescence technique to assess frequency of dividing cells and bacteriovory in natural populations of heterotrophic microprotozoa. Appl Environ Microbiol 46:1388-1393

Sorokin YI (1994) Role of plankton in the turnover of organic matter on the Great Barrier Reef, Australia. Hydrobiologia 308:35-44

Winter C, Herndl GJ, Weinbauer MG (2004) Diel cycles in viral infection of bacterioplankton in the North Sea. Aquat Microb Ecol 35:207-216

$>$ Zhang Y, Jiao N (2007) Dynamics of aerobic anoxygenic phototrophic bacteria in the East China Sea. FEMS Microbiol Ecol 61:459-469

Zhang Y, Jiao N, Hong N (2008) Comparative study of picoplankton biomass and community structure in different provinces from subarctic to subtropical oceans. DeepSea Res Part II 55:1605-1614

Appendix 1. Diel variations in the abundance of autotrophic picoplankton and in the growth rate of AAP and total bacteria

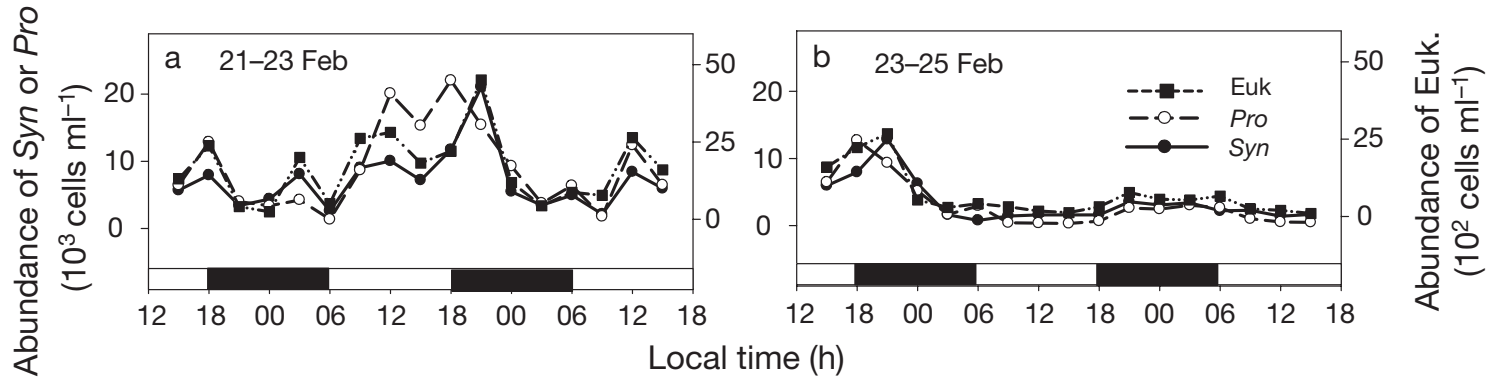

Fig. A1. Diel variations in the abundance of autotrophic picoplankton (Syn: Synechococcus; Pro: Prochlorococcus; Euk: eukaryotes) in the surface water of the sampling site. Diurnal observations were made from (a) 21 to 23 and (b) 23 to 25 February 2006.

Horizontal black (white) bars show night (day) 
Appendix 1 (continued)

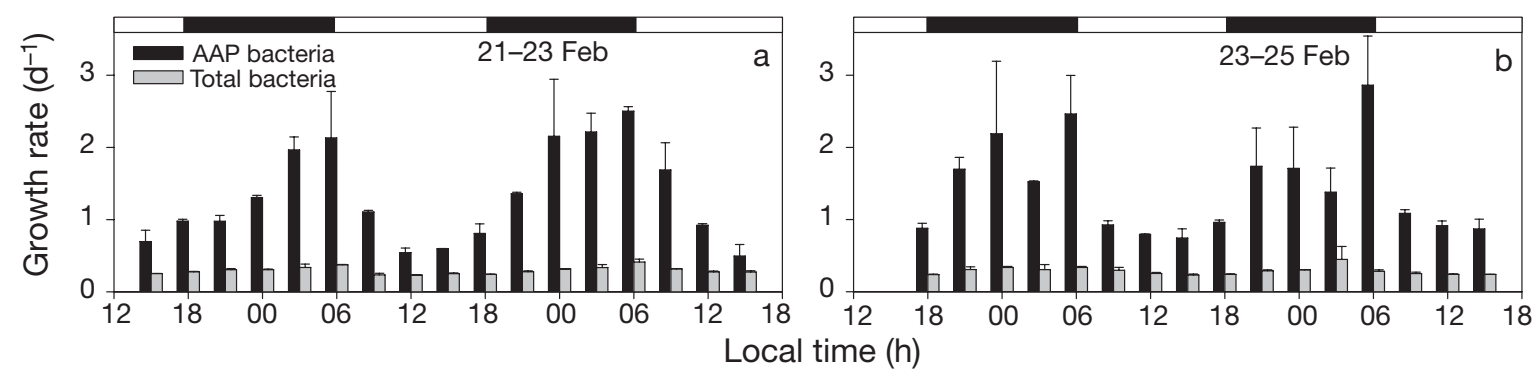

Fig. A2. Diel changes in growth rates of aerobic anoxygenic phototrophic (AAP) bacteria (black columns) and total bacteria (grey columns). Diurnal observations were made from (a) 21 to 23 and (b) 23 to 25 February 2006. Horizontal black (white) bars show night (day). Error bars indicate the SD of triplicate calculations

Editorial responsibility: Ruben Sommaruga

Innsbruck, Austria
Submitted: March 23, 2009; Accepted: September 3, 2009 Proofs received from author(s): January 19, 2010 